\title{
Relacja z konferencji „W sercu Mazowsza 105. rocznica poszerzenia granic Warszawy"
}

26 lutego br. w Muzeum X Pawilonu Cytadeli Warszawskiej - jednego z oddziałów Muzeum Niepodległości w Warszawie, miała miejsce interdyscyplinarna konferencja zamknięta, poświęcona 105. rocznicy przyłączenia do Warszawy jej dawnych przedmieść. Pragnę przypomnieć tutaj, iż w kwietniu 1916 r., po upływie ośmiu miesięcy od opuszczenia miasta przez Rosjan i - nader rychłego - zajęcia ich miejsca przez Niemców, działając z inspiracji ruchów obywatelskich, generał-gubernator Hans von Beseler wydał dekret o poszerzeniu granic Warszawy, wcześniej - zepchniętej przez Rosjan do rangi jednego z wielu miast gubernialnych imperium Romanowych i jednej z szeregu nadwiślańskich twierdz, wznoszonych na ziemiach polskich od lat 30. XIX w. W efekcie wprowadzenia w życie postanowień wspomnianego wyżej dekretu, powierzchnia miasta wzrosła niemal czterokrotnie, zaś w jego obręb włączono dotychczasowe przedmieścia, leżące na zewnątrz pasa XVIII- i XIXwiecznych umocnień. W granicach dzisiejszej stolicy znalazły się tereny, postrzegane obecnie jako rdzennie warszawskie: Rakowiec, Ochota, Mokotów, Czerniaków, Saska Kępa, Grochów, Gocław, Targówek, Bródno, Żoliborz, Młociny, Marymont i Powązki. Ów moment stał się początkiem Wielkiej Warszawy - dzisiejszej metropolii, stolicy województwa mazowieckiego i Rzeczypospolitej Polskiej.

Konferencję skierowaliśmy nie tylko do varsavianistów i miłośników lokalnej historii, ale również do działaczy samorządowych, pragnących opowiedzieć o miejscu swych lokalnych „małych ojczyzn” w dziejach i współczesności naszego regionu oraz całej Polski. Uczestnicy obrad pragnęli przybliżyć wszystkim zainteresowanym historię miasta na przestrzeni kolejnych stuleci, ze szczególnym uwzględnieniem tła historycznego i społecznego dla tytułowych wydarzeń, rozgrywających się w latach I wojny światowej. Wiele uwagi poświęcili też poszczególnym dzielnicom Warszawy, od momentu ich włączenia w obręb miasta aż po czasy nam współczesne. Podczas obrad ich uczestnicy wielokrotnie podkreślali rolę, jaką Warszawa odgrywała w przeszłości i po dziś dzień odgrywa na Mazowszu, od wielu wieków stanowiąc jego integralną część.

Ograniczenia oraz wymogi natury sanitarnej i epidemiologicznej, obowiązujące podczas organizacji samej konferencji spowodowały, że - podobnie jak liczne, poprzednie przedsięwzięcia tego typu - również wspomniane spotkanie odbyło się bez udziału publiczności, zaś jego popularyzacji posłużył przede wszystkim Internet. Seria filmów, dokumentujących jego przebieg, została zamieszczona na profilu Facebook naszej placówki, jest też dostępna na kanale muzealnym platformy YouTube, w stosownej zakładce.

Wśród lutowych wystapień przedstawicieli świata nauki należy zwrócić uwagę na szczególnie liczne referaty uczonych z Akademii Finansów i Biznesu Vistula w Warszawie: Historii Mazowsza i Warszawy konotacje doby I RP, wygłoszony przez Pana Prof. dra hab. Radosława Lolo, Warszawa, powiat warszawski, Mazowsze - o specyfice regionu podwarszawskiego w II RP 
Pani dr hab. Jolanty Załęczny oraz Podziały administracyjne na Mazowszu w XIX-XX wieku, nadesłany przez Pana Prof. dr hab. Janusza Szczepańskiego. Pani dr inż. Agnieszka Werenowska i Pani dr inż. Ewa Jaska, reprezentujące Szkołę Główną Gospodarstwa Wiejskiego, nadesłały wspólne wystapienie na temat wykorzystania nowych mediów w marketingu terytorialnym polskich miast. Pani dr hab. Dorota Mantey z Wydziału Geografii i Studiów Regionalnych Uniwersytetu Warszawskiego w interesujący sposób przedstawiła temat Wspótczesne suburbia Warszawy - problemy i wyzwania. Panie: dr inż. Ewa Janczar - Wiceprezydent Rady Gmin i Regionów Europejskich CEMR oraz mgr inż. arch. Marlena Happach - Architekt Miasta Warszawy przedstawiły prezentację multimedialną Rola planowania przestrzennego w rozwoju Warszawy. Pierwszy blok obrad zamknęło wystąpienie Pani dr Beaty Michalec - Zastępcy Dyrektora naszej placówki, zatytułowane Wielka Warszawa. Od peryferii miasta do wizji europejskiej stolicy.

Na drugi blok tematyczny złożyły się liczne prelekcje przedstawicieli władz i organów samorządowych. Pan Mariusz Frankowski - Dyrektor Mazowieckiej Jednostki Wdrażania Programów Unijnych i członek Komitetu Regionów UE wygłosił bogato ilustrowany referat Szlakiem Funduszy Europejskich po zabytkowo-kulturalnej mapie Warszawy. Pan Krzysztof Skolimowski, Zastępca Burmistrza Dzielnicy Mokotów m.st. Warszawy, w odczycie zatytułowanym Mokotów - od południowego przedmieścia do największej dzielnicy Warszawy znakomicie przybliżył ostatnie stulecie z dziejów tego obszaru. Podobnym tropem podążyła Pani Katarzyna Łęgiewicz - Burmistrzyni Dzielnicy Ochota m.st. Warszawy, przedstawiając ilustrowany referat 105 lat Ochoty - od glinianek do metropolii. Pani Dorota Kozielska - Zastępca Burmistrza Dzielnicy Targówek m.st. Warszawy przybliżyła naszym odbiorcom etapy rozwoju reprezentowanej przezeń dzielnicy na przestrzeni ostatnich dwóch wieków, zaś Pani Joanna Rutkowska z Wydziału Sportu, Promocji i Komunikacji Społecznej dla Dzielnicy Wola Urzędu m.st. Warszawy przypomniała o historycznych uwarunkowaniach potrzeby integracji społeczno-gospodarczej tego obszaru. Pani Agata Marciniak-Różak - Zastępca Burmistrza Dzielnicy Żoliborz m.st. Warszawy zaprezentowała temat Żoliborz na tle dziejów miasta w latach 1796-1945, zaś Pan Andrzej Malina, pełniący analogiczną funkcję w Dzielnicy Bielany - opowiedział o jej historii przez pryzmat sportu i rekreacji, od wielu dziesięcioleci będących swoista jej wizytówka.

Ostatni - trzeci blok - obejmował wystapienia muzealników. Pan kustosz Mariusz Raniszewski z Państwowego Muzeum Etnograficznego w Warszawie niezwykle barwnie opowiedział o Nadwiślańskim Urzeczu jako krainie ludzi wolnych. Pracownicy poszczególnych oddziałów Muzeum Niepodległości w Warszawie przygotowali aż pięć referatów. Pan kustosz Andrzej Kotecki przedstawił bogato ilustrowana prezentację Historia Warszawy medalem pisana. Wybrane pamiatki I wojny światowej w zbiorach Muzeum Niepodległości, Pan kustosz Łukasz Żywek - nie mogąc osobiście wziąć udziału w obradach, nadesłał tekst zatytułowany „Dnia 5 sierpnia 1915 r. Warszawa została zajęta przez Niemców..." Pamiatki niemieckiej okupacji Warszawy z lat 1915-1918 w zbiorach Muzeum Niepodległości w Warszawie. O roli Cytadeli Warszawskiej w polityce władz zaborczych doby Wielkiej Wojny opowiedział Pan adiunkt Michał Cieślak z przywołanego już na samym początku Muzeum X Pawilonu Cytadeli 
Warszawskiej, zaś Jego przełożony - Pan kustosz Jan Engelgard - o nastrojach panujących wśród ludności Warszawy w latach 1914-1916. Autorowi niniejszej relacji przypadł w udziale zaszczyt przygotowania referatu zatytułowanego Obraz Wielkiej Wojny i okupacji niemieckiej 1915-1918 w pamiętnikach mieszkańców i prasie warszawskiej.

Wygłoszone 26 lutego wystapienia zostały opublikowane w sieci, w formie filmu dokumentującego przebieg całych obrad. Muzeum Niepodległości w Warszawie pracuje również nad wydaniem w najbliższym czasie stosownej, recenzowanej publikacji pokonferencyjnej, zawierającej także treść zgłoszonych uprzednio wystapień, do których nie doszło z przyczyn niezależnych od prelegentów.

Opisane wyżej przedsięwzięcie, odbywające się w przededniu kolejnej rocznicy wydarzeń, istotnych zwłaszcza dla naszej historii lokalnej, zorganizowaliśmy przy współudziale Instytutu Badań w Dyscyplinie Historia Akademii Finansów i Biznesu Vistula oraz Towarzystwa Przyjaciół Warszawy. Zostało ono objęte dwoma - szczególnie dobrze podkreślającymi jego stołeczny i regionalny charakter - patronatami honorowymi: Prezydenta Miasta Stołecznego Warszawy i Marszałka Województwa Mazowieckiego.

dr Pawet Bezak

Paweł Bezak, phm., dr - historyk i muzealnik, od 2006 roku - kolejno wolontariusz i instruktor stołecznego Muzeum Harcerstwa, obecnie - jego dyrektor. W latach 2007-2021 - pracownik merytoryczny Muzeum Niepodległości w Warszawie oraz jego oddziału Muzeum Więzienia Pawiak. Autor licznych artykułów o tematyce historycznej, autor i współautor publikacji książkowych, katalogów i informatorów wystaw, współautor ekspozycji stałych, czasowych i planszowych w obu wspomnianych placówkach muzealnych. Przez ostatnie lata prowadził badania zwiq̨zane z dziejami Legionów Polskich.

Paweł Bezak, PhD - Petty Scoutmaster; historian and museologist, since 2006 - successively a volunteer and instructor in the Museum of Scouting in Warsaw, currently - its director. In the years 2007-2021 - the employee of the Museum of Independence in Warsaw and its branch - Museum of Pawiak Prison. Author of numerous articles on history, author and co-author of book publications, catalogues and exhibition guides, co-author of permanent, temporary and board exhibitions in both above mentioned museums. In recent years, he has conducted research related to the history of the Polish Legions. 
